\title{
Different Images of Black Women in American Literature: From the Eyes of Black and White Female Writers
}

\author{
Qingyi Xu \\ East China University of Science and Technology, Shanghai, China \\ Email: 1286334981@qq.com
}

How to cite this paper: Xu, Q.Y. (2021) Different Images of Black Women in American Literature: From the Eyes of Black and White Female Writers. Open Access Library Journal, 8: e7329. https://doi.org/10.4236/oalib.1107329

Received: March 19, 2021

Accepted: April 9, 2021

Published: April 12, 2021

Copyright $\odot 2021$ by author(s) and Open Access Library Inc.

This work is licensed under the Creative Commons Attribution International License (CC BY 4.0).

http://creativecommons.org/licenses/by/4.0/

\section{(c) (i) Open Access}

\begin{abstract}
To Kill a Mockingbird and Their Eyes Were Watching God are two famous novels focusing on black people. Starting with four stereotypes of black women, this paper analyzes the different images of black women in American Literature, exampled by white woman writer Harper Lee and black woman writer Zora Neale Hurston in their respective works, and discusses the influence of mainstream culture on the image of black women, calling on people to pay more attention to black women groups.
\end{abstract}

\section{Subject Areas}

Literature

\section{Keywords}

Stereotypes of Black Women, Harper Lee, Zora Neale Hurston, American Literature

\section{Introduction}

In the 19th century, many female writers paid attention to women's status and race problem, but not many writers mentioned them at the same time. When the author read Bell Hooks's book Ain't I a Woman: Black Woman and Feminism (1981), she found that Bell deconstructed and restored the literary and artistic texts of white and black men and the stereotyped images of black women in movies. She combed out several popular negative images of black women, revealed the strategies of racism, classism and sexism hidden behind them, and pointed out the truth of restoring the true image of black women in history, that is, creating a new image on the premise of establishing the subjectivity of black 
women. Her criticism of black feminism has irreplaceable value and significance in sending out the weak voice of marginal groups to the world and promoting the status of black women. There are two different images of black people in To Kill a Mockingbird and Their Eyes Were Watching God, which both are impressive in American literature: the black people in the white writers' works are in line with the black people in the eyes of the mainstream American culture at that time, while the black writers actively speak out, trying to break the inherent impression of black people in American society. It is worth studying that black female have completely different self-consciousness in the works of white and black female authors. And in the study, the author found that the voice of black writers has caused certain changes to the stereotype of black women in American mainstream culture.

\section{Four Stereotypes of Black Women in American Literature}

In her book, Bell Hooks generalized three forms of black women's images: prostitutes who is a sexual object or sexually indulgent, mammy and matriarch. After analyzing the images of black women in traditional literature, Patricia Hill Collins, a black feminist critic, summarized them into four stereotyped images, namely, the loyal and docile mammy, the manipulative and aggressive matriarch, the lazy and irresponsible welfare mother and the provocative jezebel $[1]$.

\subsection{Loyal and Docile Mammy}

The image of black women as faithful mammies is very popular in American popular culture. Hu Jing's paper mentioned: “Black nannies are usually obese, ugly in appearance and speak poor English, but they have religious beliefs, loyalty, kindness, strong body, hard-working spirit but no complaints. They are a group of maids who have no self-needs or sexual desire, and only follow orders." [2]. In the book Black Feminist Thought. Knowledge, Consciousness, and the Politics of Empowerment, written by Patricia Hill Collins, a black woman recounted a story like this: "In 1967 ... once I was pushing my 2-year-old daughter with a shopping cart in a supermarket. A little white girl passed me in her mother's cart and excitedly shouted, 'Look, mother, a nanny?" [1], which shows that the concept of black women as nannies is deeply rooted in the United States. This kind of image "makes black women subject to the legalization of domestic service for a long time and becomes the standard scale for evaluating black women." [3].

\subsection{Provocative Jezebel}

Bell hooks mentioned in her book Ain't I a Woman: Black Woman and Feminism that by disparaging black women as lascivious women, white men have diverted the public's attention from their violent acts of sexual assault. "Black women were naturally seen as the embodiment of female evil and sexual lust. 
They were labeled jezebels and sexual temptresses and accused of leading white men away from spiritual purity into sin." [4].

\subsection{Manipulative and Aggressive Matriarch}

In 1965, Danial Moynihan's report “The Negro Family: The Cast for National Action" [5] discussed black women's mastership at home as the cause of black poverty, which made black "female parents" a negative image. According to the report, it is because the black women were too fierce and failed to perform their duties that there were so many problems in the black community. For example, they were not considerate in taking care of their children, resulting in poor grades of black children, or they were abandoned by their lovers because they lacked femininity. Mainstream condemned the image of "failed mother" of black female, and used this image to show that the economic poverty and low class of black people were due to the incompetence of matriarch, thus obscuring the political and economic inequality in the social structure.

\subsection{Lazy and Irresponsible Welfare Mother}

The image of welfare mother is described as a single mother who "avoids work, just sits there waiting for welfare payment satisfactorily" [3]. American society even attributed the economic and moral problems to the existence of welfare mothers, which is still an effective example of multiple oppressions on the black female.

\section{The Image of Black Women from the Eyes of the White Female Writer Harper Lee}

\subsection{Harper Lee and Her Novel To Kill a Mockingbird}

From the perspective of a little white girl named Scout, To Kill a Mockingbird mainly tells the story of her lawyer father Atticus defending a black man and its influence in the town. The story was set in America during the Great Depression. Although Lincoln had already signed the Emancipation Proclamation, white people in the United States at that time, especially in the south, still had the idea of racial discrimination. Because of the Civil War, most Americans had abandoned the discrimination against blacks, but some stubborn Americans still insisted on calling blacks niggers and refused to respect them.

The novel focuses on the racial discrimination and contradiction between whites and blacks. Besides, Harper Lee also depicts the care and teaching of the black nanny Calpurnia to Scout and her brother Jem during their adolescence. Although Calpurnia is a positive image in the book, readers can still see the stereotype of black women showed by the white female writer Harper Lee.

\subsection{The Image of Black Women in To Kill a Mockingbird}

In To Kill a Mockingbird, Calpurnia, a black nanny, is a typical black female image written by a white writer. At the beginning of the novel, Calpurnia is in- 
troduced as follows:

"Calpurnia was something else again. She was all angles and bones, she was nearsighted; she squinted; her hand was wide as a bed slat and twice as hard. She was always ordering me out of the kitchen, asking me why I couldn't behave as well as Jem when she knew he was older, and calling me home when I wasn't ready to come. Our battles were epic and one-sided. Calpurnia always won, mainly because Atticus always took her side. She had been with us ever since Jem was born, and I had felt her tyrannical presence as long as I could remember."

"For some reason, my first year of school had wrought a great change in our relationship: Calpurnia's tyranny, unfairness, and meddling in my business had faded to gentle grumblings of general disapproval. On my part, I went to much trouble, sometimes, not to provoke her."

It can be seen that Calpurnia is bossy, unreasonable and easily angered in Scout's eyes, which is consistent with the characteristics of black women's ferocity and lack of femininity in mainstream culture.

Calpurnia represents a loyal nanny of Finch's family who takes care of housework with devotion and plays an indispensable role in the growth of Jem and Scout. Before Calpurnia took Jem and Scout to the black church, she gave them a thorough bath because "I don't want anybody sayin' I don't look after my children." In children's eyes, Calpurnia is a kind mother image, giving them not only delicious food but also endless care. This indicates that Calpurnia already regarded Jem and Scout as her own children, but Calpurnia didn't care much about her real children. This even surprised Scout, who never thought that Calpurnia was living a double life outside her home:

"That Calpurnia led a modest double life never dawned on me. The idea that she had a separate existence outside our household was a novel one, to say nothing of her having command of two languages."

In Harper Lee's eyes, the duty of a black nanny is to take good care of her master's family and has no other pursuit or goal of life. The characteristic of black nannies is to be willing to devote herself to the work for the white people.

When Calpurnia took Jem and Scout to the church of the blacks, they learned that the black people's educational level was so low that they didn't need pamphlets of hymns in the church, and the members all finished the songs by singing along. For Scout's doubts about why Calpurnia didn't use grammar correctly in church like a white man, she answered:

"It's not necessary to tell all you know. It's not ladylike-in the second place, folks don't like to have somebody around knowin' more than they do. It aggravates 'em. You' re not gonna change any of them by talkin' right, they' ve got to want to learn themselves, and when they don't want to learn there's nothing you can do but keep your mouth shut or talk their language."

This shows that in the American society at that time, the status of black women was not as high as that of men. Bell Hooks wrote in her book: "When 
black women failed for whatever reason to assume a passive subordinate role in relationship to black men, the men became angry." [4]. Even if women know more knowledge and culture, it is not something they should be proud of. Instead, they try to disguise themselves to avoid aggravating men or causing conflict.

The stereotype of black women in mainstream culture also leads to the growing hostility of white women to black women. Aunt Alexandra's inexplicable dislike of blacks such as Calpurnia also stems from this kind of prejudice. Alexandra assumed that all blacks lie, all blacks are basically immoral, and all blacks are untrustworthy. She did not allow Calpurnia to cook delicious food for Rice Christians, a Missionary Society with Aunt Alexandra as its hostess, because from Alexandra's point of view, Calpurnia's black identity would ruin the sanctity of white organizations.

\section{The Image of Black Women from the Eyes of the Black Female Writer Zora Neale Hurston}

\subsection{Zora Neale Hurston and Her Novel Their Eyes Were Watching God}

Their Eyes Were Watching God mainly tells about three marriages of a black woman Janie. In three different marriages, she didn't seek the meaning of happiness and life until she shot her third husband. The death of Tea Cake finally freed Janie from the shackles of male dominance.

During the Harlem Renaissance, the works of black female writers like Hurston showed many characteristics different from those of black male writers due to their special identities and experiences, which reflected the strong desire of black women to actively construct their racial identities in a white-dominated and male-dominated social environment. At the beginning of the novel, the author tells the life of three generations by her grandmother's words: Janie had to live alone with her grandmother since childhood because of her mother's running away from home. As a black woman, her grandmother worked as a slave for white people for a living, but her greatest ideal was to own a small piece of her own land and arranged a wedding for Janie. From the characteristics of grandmother and Jenny, readers can see the independent spirit of black women living for themselves.

This is the first novel that transcends racial issues and fully demonstrates the awakening of black women's consciousness and self-salvation. It is also a genius work written in poetic language, and is known as one of the greatest works in Harlem Renaissance. From black women's point of view, Hurston shouted for her own group, trying to break the mainstream stereotype of black women.

\subsection{The Image of Black Women in Their Eyes Were Watching God}

Hurston, on the other hand, spoke for black women, trying to break the traditional image of black nannies and sluts in the eyes of white people and show 
their true thoughts. In Their Eyes Were on God, Nanny's life goal is not only to work for the white master. She lived for herself and her daughter.

"Ah was born back due in slavery so it wasn't for me to fulfill my dreams of whut a woman oughta be and to do. Dat's one of de hold-backs of slavery. But nothing can't stop you from wishin'. You can't beat nobody down so low till you can rob 'em of they will. Ah didn't want to be used for a work-ox and a brood-sow and Ah didn't want mah daughter used dat way neither. It sho wasn't mah will for things to happen lak they did."

She resisted stereotypes such as work-ox and brood-sow. But her status as a slave prevented her from realizing her dream. She could see the constraints imposed on her body, but hard to break free. Therefore, nanny taught Janie to have self-respect and tried to make her granddaughter live a better life.

"Ah raked and scraped and bought dis lil piece uh land so you wouldn't have to stay in de white folks' yard and tuck yo' head befo' other chillun at school. Dat was all right when you was little. But when you got big enough to understand things, Ah wanted you to look upon yo'self. Ah don't want yo' feathers always crumpled by folks throwin' up things in yo' face. And Ah can't die easy thinkin' maybe de menfolks white or black is makin' a spit cup outa you."

Although Nanny's ideal life for Janie is not what Janie pursued, Nanny's words planted a seed in the heart of young Janie and taught her to resist traditional customs and strive for freedom and equality.

Another stereotype of black women as sluts illustrates the prejudice against the sexual desire of them in American society. In the slavery era in the United States, black women's bodies belonged to their white masters. "To him, she was a disassembled commodity, and her feelings and choices hardly needed to be taken into consideration. Her head and heart were separated from her hands and back, separated from her uterus and vagina." [6]. Black women have given birth to many hybrids after being raped by their white masters. White people who opposed intermarriage attributed the birth of hybrids to immorality of black women, claiming that white men were induced to have sex with black women. This is clearly shown in Their Eyes Were Watching God through Nanny's dialogue with the heroine Janie:

"But pretty soon he let on he forgot somethin' and run into mah cabin and made me let down mah hair for de last time. Hesorta wropped his hand in it, pulled mah big toe, lak he always done, and was gone after de rest lak lightnin'".

In the eyes of the white male master, Nanny was his property and could be treated arbitrarily. However, in the eyes of the white hostess, Nanny was seducing the white male master, which must be severely punished. After being discovered by the hostess that her daughter had gray eyes and yellow hair, Nanny was threatened by her that the overseer would whip her the next morning, and her child would also be sold. Nanny did not resign herself to her fate, but rebelled against it and ran away overnight with her daughter, hiding in the swamp. However, fate played a joke on Nanny again. When her daughter was 17 years old, she was raped by a school teacher. A school teacher, even a knowledgeable 
man, held the view that black women could be abused. Because they have been oppressed for a long time, they cannot vent their grief and anger, but can only heal themselves silently. Hurston wants to announce loudly to the world through her works that black women are not sluts who seduce white men. They are the real victims and vulnerable groups. There is nothing wrong with black women. What is wrong is the stereotype imposed on black women by mainstream culture, racial discrimination and gender discrimination.

During the Harlem Renaissance, the works of black female writers like Hurston showed many characteristics different from those of black male writers due to their special identities and experiences, which reflected the strong desire of black women to actively construct their racial identities in a white-dominated and male-dominated social environment. Their works presented some refreshing new female images. One of the most important purposes of black female writers in the Harlem Renaissance is to correct the distortion of black images, especially black women images, in previous literary works. Their novels truly reflect the profound influence of the double oppression of racism and gender discrimination on black women in American society. They also hope to express their feelings and show a complete self by writing novels. In their works, readers can clearly see the image of a new generation of mixed-race women fighting for their independence and spiritual liberation. They are not only beautiful and intelligent, but also full of rebellious spirit. While pursuing a better life, they are struggling for spiritual independence and liberation, and trying to break free from the invisible social shackles.

\section{The Influence of Mainstream Culture on the Image of Black Women in American Literature}

Through the above text analysis, it is not difficult to see that in the eyes of white writers and black writers, the images of black women are polarized. Here is a table to summarize the differences of black women's images in the novel (Table $1)$.

Table 1. The differences of black women's images in To Kill a Mockingbird and Their Eyes Were Watching God.

\begin{tabular}{lll}
\hline & $\begin{array}{c}\text { Black Women in To } \\
\text { Kill a Mockingbird }\end{array}$ & $\begin{array}{c}\text { Black Women in Their Eyes } \\
\text { Were Watching God }\end{array}$ \\
\hline Temperament & $\begin{array}{l}\text { a loyal nanny but bossy, } \\
\text { unreasonable and easily angered. }\end{array}$ & $\begin{array}{l}\text { Self-reliance, independence } \\
\text { and kindness. }\end{array}$ \\
Goal of Life & To serve the white people. & $\begin{array}{l}\text { To pursue their own } \\
\text { happiness of life. }\end{array}$ \\
The General Impression & $\begin{array}{l}\text { All blacks lie, all blacks are } \\
\text { basically immoral, and all } \\
\text { blacks are untrustworthy. }\end{array}$ & $\begin{array}{l}\text { Black women are by no means } \\
\text { seductive slut, but brave women } \\
\text { with tough hearts. }\end{array}$ \\
Interpersonal Relationship & Alone, with no friend. & $\begin{array}{l}\text { The novel begins with a } \\
\text { heart-to-heart talk between black } \\
\text { women. }\end{array}$ \\
\hline
\end{tabular}


As a native black, Hurston has a profound understanding of the situation of the black community, especially the life of black women. Therefore, her literary works infiltrate her unique perspective as a black woman. The focus of white female writers is generally on the work, occupation, welfare, psychological and emotional conditions of white women, especially the power distribution and gender advantages and disadvantages with white male groups, which is a topic that they argue frequently, while they pay little attention to the situation of women of marginal races. As a black feminist writer, Hurston pays more attention to black women who have been neglected in feminist movement and feminist theoretical research. Hurston witnessed and experienced gender oppression in black society in her childhood, so in the early 1920s, she mainly criticized the double oppression of gender and race suffered by black women. In the 1930s, Hurston resisted sexism by exaggerating the imagination of women's power. In the 1940s, because of the Great Depression in the 1930s and the subsequent World War II, the focus of American society and literature turned to a broader social problem that transcended race and gender opposition, and African-American literature showed a trend of merging into American mainstream literature. At the same time, Hurston has repeatedly revealed an individualistic tendency that transcends race, gender and culture in her autobiography.

Moreover, her concern is different from that of white feminists. As far as the relationship between women is concerned, white feminists began to explore this issue very early. They studied this topic either through literary creation or criticism. However, due to the scope and vision of life, they never broke through the boundaries of white people and failed to consider the complexity and diversity of life. Similar problems are mentioned in Hooks's book. As a black critic, she affirmed the possibility of alliance among women, but this kind of unity is not limited to the relationship between black women, but also includes the relationship between black women and white women. She criticized the discourse hegemony of white feminists and the rejection of black women in the feminist movement. However, in this respect, instead of being as general as the criticism of white women, she participated in women's group activities many times to observe the internal situation and situation. She found that the reasons for the problems of black women lie not only in the internal black women or between black women and white women, but also in the cultural and social environment, and in the patriarchal cultural system dominated by white people.

The impression of American mainstream culture on black women has changed to some extent, but it is far from complete equality. There is still a long way to go to make the status of black women equal to that of white women and even white men, which requires not only the efforts of black women themselves, but also the efforts of all women and all egalitarians.

\section{Conclusions}

Although both novels were written in the 20th century, they still have signific- 
ance today in the 21 st century. Up to now, there are still many black women who suffer from discrimination and unfair treatment, which is the shackle put on them by the mainstream. Although some black women have integrated into the upper or middle class of the social structure, most black women in the United States are still under tremendous mental pressure. In 2014, Donovan's study quantitatively examines the relationships among the Strong Black Woman stereotype (SBW) endorsement, stress, and anxious and depressive symptoms with a sample of 92 Black female college students [7]. Results revealed that embracing the SBW stereotypic image increases Black women's vulnerability to depressive symptoms associated with stress.

Hurston exerts herself to establish an independent and thinking image of black women, and tries to construct the subjectivity of black women through words and literature, thus completing the self-naming and correct expression of the black women. From her novels, we learn more about their living environment from writers or artists who represent their race and gender, instead of being brainwashed by mainstream culture. Hurston described the life of black people with her own works, threw away the hat worn by American mainstream society for black women, and presented the real black women image to the world. We should try our best to remove the mask brought by mainstream society to minority groups and take the initiative to fight for equal rights.

\section{Conflicts of Interest}

The author declares no conflicts of interest regarding the publication of this paper.

\section{References}

[1] Collins, P.H. (1990) Black Feminist Thought: Knowledge, Consciousness, and the Politics of Empowerment. Unwin Hyman, Boston.

[2] 胡静. 颠覆与重塑——《所罗门之歌》黑人女性形象 [J]. 吉林省教育学院学报(上 旬), 2014, 30(7): 129-131.

[3] 赵思奇. 贝尔.胡克斯黑人女性主义文学批评研究 $[M]$. 北京: 中国社会科学出版 社, 2014.

[4] Hooks, B. (1981) Ain't I a Woman: Black Woman and Feminism. South End Press, Boston.

[5] Moynihan, D.P. (1967) The Moynihan Report: The Negro Family: The Case for National Action. The Moynihan Report and the Politics of Controversy, 39-124. (Print)

[6] Omolade, B. (1994) The Rising Song of African American Women. Routledge, New York.

[7] Donovan, R.A. and West, L.M. (2014) Stress and Mental Health: Moderating Role of the Strong Black Woman Stereotype. Journal of Black Psychology, 41, 384-396. https://doi.org/10.1177/0095798414543014 